\title{
POLA PERTUMBUHAN PASAR RAKYAT DI KOTA PONTIANAK
}

\author{
Emilya Kalsum \\ Jurusan Arsitektur, Fakultas Teknik, Universitas Tanjungpura \\ kalsum.emilya@gmail.com

\section{Yudi Purnomo} \\ Jurusan Arsitektur, Fakultas Teknik, Universitas Tanjungpura \\ yudipurnomo@teknik.untan.ac.id
}

Naskah diajukan pada: 16 Juni 2019

Naskah revisi akhir diterima pada: 11 Desember 2019

\begin{abstract}
Abstrak
Pasar tradisional atau pasar rakyat merupakan sebuah pusat kegiatan ekonomi di suatu daerah yang juga menjadi perwujudan kesejahteraan masyarakat sangat berpotensi dalam menggerakkan roda perekonomian berbasis ekonomi rakyat. Pasar rakyat mampu bertahan memberikan pelayanan kebutuhan kepada masyarakat luas sekalipun dalam kondisi krisis perekonomian. Pasar rakyat telah menggambarkan denyut nadi perekonomian rakyat. Oleh karena itu, sangatlah penting untuk menyelamatkan keberadaan pasar rakyat yang kini semakin terhimpit oleh adanya pasar modern yang terus meningkat saat ini. Pemerintah telah memiliki berbagai kebijakan untuk mengantisipasi masalah ini di antaranya adalah Peraturan Presiden Nomor 112 tahun 2007 tentang Penataan dan Pembinaan Pasar rakyat, Pusat Perbelanjaan dan Toko Modern. Namun berbagai kebijakan seringkali hanya diberlakukan pada pasar rakyat yang disediakan atau dibangun oleh pemerintah atau pengelola wilayah. Padahal tak jarang, pasar rakyat yang ada berawal dari pasar yang tumbuh dari swadaya masyarakat. Pasar seperti ini hampir merata tumbuh di setiap kota di Indonesia demikian pula di Kota Pontianak. Identifikasi pola pertumbuhan pasar rakyat di Kota Pontianak ini dimaksudkan untuk mengetahui bagaimana sebetulnya sebuah pasar rakyat tumbuh dan berkembang di area permukiman. Penelitian ini menggunakan metode deskriptif dengan pendekatan kuantitatif, dalam upaya mendeskripsikan gejala atau fenomena tentang pertumbuhan yang terjadi pada saat penelitian dilakukan. Pendekatan kuantitatif dilakukan dalam rangka untuk mengetahui jumlah pasar rakyat hasil swadaya masyarakat. Pola pertumbuhan pasar rakyat di Kota Pontianak yang terbentuk dari swadaya masyarakat Kota Pontianak yang ditunjukkan dari hasil penelitian ini sangat relevan untuk menjadi pertimbangan dalam penataan pasar rakyat di Kota Pontianak di masa yang akan datang. Ini terkait pada kebutuhan masyarakat, lokasi, kepemilikan, penempatan dan pengelolaan.
\end{abstract}

Kata-kata Kunci: Pasar rakyat, pola, pertumbuhan

\section{PUBLIC MARKETS GROWTH PATTERN IN PONTIANAK}

\begin{abstract}
Traditional markets or public markets are the centers of economic activity in an area that also embody the welfare of the people who have great potential and can drive the economy of the people. During financial crisis, the markets can survive, providing service needs to the community. Public markets have described the pulse of the people's economy. Therefore, the existence of public markets, which are now increasingly squeezed by the rapid growth of the modern stores, are important to be


immediately saved. The government already has several legal protections to overcome this problem, one of it is the Presidential Regulation Number 112 of 2007 concerning the Arrangement and Development of Public Markets, Shopping Centers and Modern Stores. However, various policies are often only applied to the public markets that are provided or built by the government or regional managers. Even though it is not uncommon that the existing public markets originated from markets that grow from nongovernmental community self-help. These markets are almost evenly grown in every city in Indonesia, as well as in Pontianak. Identification of the pattern of growth of the public markets in Pontianak is intended to find out how public markets grow and develop in residential areas. This research uses a descriptive method with a quantitative approach, to describe the symptoms or phenomena about the growth that occur at the time the research is conducted. A quantitative approach is carried out to find out the number of people's markets resulting from nongovernmental community self-help. The results showed that the pattern of growth of public market in Pontianak which was formed from the self-help of the people was very relevant to be considered in the structuring of the public markets in Pontianak in the future. This is related to community needs, location, ownership, placement, and management.

Keywords: public market, pattern, growth

\section{Pendahuluan}

Pasar tradisional merupakan sebuah pusat kegiatan ekonomi di suatu daerah yang juga menjadi perwujudan kesejahteraan masyarakat. Penggunaan istilah "pasar tradisional" berubah menjadi "pasar rakyat" tertuang dalam Undang-Undang Nomor 7 Tahun 2014 tentang Perdagangan. Peraturan Presiden RI No. 112 Tahun 2007 menatakan bahwa pasar rakyat adalah pasar yang dibangun dan dikelola oleh pemerintah daerah, swasta, badan usaha milik Negara dan badan usaha milik daerah termasuk kerjasama dengan swasta dengan tempat usaha berupa toko, kios, los dan tenda yang dimiliki atau dikelola oleh pedagang kecil, menengah, swadaya masyarakat atau koperasi dengan usaha skala kecil, modal kecil dan dengan proses jual beli barang dagangan melalui tawar menawar.

Pasar rakyat sangat berpotensi menggerakkan roda perekonomian berbasis ekonomi rakyat. Ini karena adanya aktivitas perdagangan dan perannya sebagai tempat untuk pemenuhan kebutuhan hidup masyarakat dengan harga yang sesuai. Sebagai sarana penggerak roda perekonomian, pasar rakyat terbukti mampu bertahan dan memberikan pelayanan kebutuhan dalam kondisi krisis bahkan untuk masyarakat berpenghasilan rendah. Pasar rakyat juga mampu menyediakan lapangan kerja di berbagai sektor informal.

Persaingan antara pasar rakyat dan retail modern saat ini tidak bisa dihindari. Membanjirnya retail modern menjadi ancaman bagi keberadaan pasar rakyat. Kebijakan Pemda menjadi sangat dibutuhkan untuk melindungi kebutuhan masyarakat akan pasar rakyat. Pasar rakyat wajib dilindungi pemerintah agar mampu bertahan sehingga dapat menjadi ruang kegiatan ekonomi. Nilai strategis lainnya dari pasar rakyat adalah adanya nilai sosial budaya yang sesuai dengan budaya bangsa Indonesia.

Meskipun demikian, pasar modern tidak memiliki keunggulan bersaing alamiah sebagaimana pasar rakyat. Keunggulan ini di antaranya adalah lokasi strategis, luasnya area penjualan, keragaman dan kelengkapan barang yang diperdagangkan, harga yang rendah dengan sistem tawar menawar. Selain perspektif untung-rugi, transaksi perdagangan di pasar rakyat juga dapat dilihat sebagai tempat pemenuhan kebutuhan sosial berupa penghargaan serta ikatan hubungan emosional antar personal. Selain mendapat barang yang diperlukan, pembeli juga mendapat tempat sebagai sarana bersosialisasi. Proses tawar-menawar dalam proses transaksi merupakan interaksi sosial yang saling 
memuaskan. Itu sebabnya, penting untuk segera menyelamatkan pasar rakyat yang kini semakin terhimpit keberadaannya dari pesatnya pertumbuhan pasar modern.

Dalam rangka penataan pasar rakyat secara umum, Pemerintah telah memiliki payung hukum yaitu Peraturan Presiden Nomor 112 tahun 2007 tentang Penataan dan Pembinaan Pasar Tradisional, Pusat Perbelanjaan dan Toko Modern. Peraturan ini menyebutkan bahwa Pemerintah dan Pemda baik secara sendiri-sendiri maupun bersama-sama sesuai dengan bidang tugas masing-masing melakukan penataan, pembinaan dan pengawasan pasar tradisional. Peraturan ini pada dasarnya menjadi pedoman awal bagi beragam program penataan dan revitalisasi pasar rakyat.

Berbagai kebijakan yang ada kenyataannya seringkali hanya diberlakukan pada pasar rakyat yang disediakan atau dibangun oleh pemerintah atau pengelola wilayah. Padahal tak jarang, pasar rakyat yang ada berawal dari pasar yang tumbuh dari swadaya masyarakat pada sebuah permukiman. Biasanya pasar ini muncul di sepanjang jalan menuju komplek perumahan, perempatan jalan, lapangan atau lahan kosong yang dekat permukiman warga yang sama sekali tidak berfungsi sebagai lokasi pasar. Pasar seperti ini hampir merata tumbuh di setiap sudut kota-kota di Indonesia demikian pula di Kota Pontianak. Hal ini tidak lepas dari faktor tingginya minat warga mengunjungi pasar tersebut. Ini dimungkinkan terjadi akibat kemajuan jaman dan kemanjaan masyarakat terhadap situasi serta banyaknya kesibukan rutinitas yang dilakukan. Masyarakat ingin segalanya serba dekat dan cepat dijangkau. Selain memberikan kemudahan kepada warga di sekitarnya, pasar ini juga menjadi wadah untuk warga lain yang tidak memiliki pekerjaan untuk berdagang. Adanya dua kebutuhan yang saling melengkapi antara pembeli dan pedagang, seringkali membuat pasar seperti ini lebih berkembang daripada pasar rakyat yang dibangun secara resmi oleh pemerintah.

Berangkat dari kondisi ini, penelitian ini selanjutnya bertujuan untuk mengidentifikasikan proses pertumbuhan pasar swadaya masyarakat dalam sebuah permukiman menjadi pasar rakyat yang permanen terkait kebutuhan masyarakat, lokasi, kepemilikan, penempatan dan pengelolaan. Penelitian ini diharapkan dapat menjadi acuan pertimbangan untuk Kota Pontianak dalam membuat model penataan pasar rakyat.

\section{Kajian Pustaka}

\section{Pengertian Pasar Rakyat}

Terminologi pasar rakyat pada mulanya berawal dari pasar tradisional yang tertuang dalam penjelasan Pasal 12 Ayat (1) Undang-Undang Nomor 7 Tahun 2014 tentang Perdagangan. Dijelaskan bahwa "Pasar Rakyat" adalah tempat usaha yang ditata, dibangun, dan dikelola oleh Pemerintah, Pemerintah Daerah, swasta, Badan Usaha Milik Negara, dan/atau Badan Usaha Milik Daerah dapat berupa toko, kios, los, dan tenda yang dimiliki/dikelola oleh pedagang kecil dan menengah, swadaya masyarakat, atau koperasi serta usaha mikro, kecil, dan menengah dengan proses jual beli Barang melalui tawar-menawar.

\section{Pasar Rakyat Sebagai Penggerak Ekonomi Lokal}

Beberapa penelitian mengatakan bahwa masyarakat dengan status sosial ekonomi menengah ke atas cenderung beralih berbelanja ke pasar modern sebagaimana banyak ditemukan dalam beberapa penelitian (Appel, 1972; Goldman, 1981; Kaynak and Cavusgil, 1982; Kumcu and Kumcu, 1987; Findlay et al., 1990). Pertumbuhan pasar modern yang terus meningkat di Thailand dikatakan semakin menghilangkan fungsi pasar rakyat (Schipmann dan Qaim, 2011). Penyebab lainnya yang diungkapkan oleh Slater dan Henley (1969) adalah karena proses jual beli di pasar rakyat merupakan multi-shop stopping. Pembeli harus mengunjungi dan melakukan proses jual beli dan tawar menawar secara berulang pada beberapa toko/tenant. Sementara di pasar modern yang memiliki konsep onestop shopping dianggap tidak membutuhkan opportunity cost serta tenaga lebih. Pergeseran ini menjadi hal yang cukup wajar terutama jika terjadi pada masyarakat dengan status sosial ekonomi menengah atas. 
Meskipun demikian, Suryadarma, et al (2007) mengatakan bahwa permasalahan utama menurunnya pasar rakyat di Indonesia lebih disebabkan oleh masalah internal yaitu permasalahan antar penjual di lapangan. Penelitian Goldman dan Hino (2005), membuktikan bahwa faktor etnis dan geografis memberi pengaruh yang bertolak belakang. Penelitian ini mengatakan bahwa pasar rakyat lebih dipilih oleh masyarakat dengan status sosial ekonomi menengah atas dibandingkan pasar modern. Jarak pasar rakyat yang umumnya berada di dekat permukiman membuatnya lebih mudah dijangkau dibandingkan pasar modern yang cenderung berada di tengah kota. Selain jarak, variasi dan kondisi produk yang lebih segar juga menjadi alasan yang cukup kuat bagi masyarakat memilih untuk berkunjung ke pasar rakyat. Itu sebabnya pasar rakyat yang merupakan tempat pemenuhan kebutuhan sehari-hari masyarakat memiliki potensi yang besar sebagai penggerak ekonomi lokal.

\section{Pendirian dan Pengelolaan Pasar Rakyat}

Lokasi pendirian pasar rakyat yang disebutkan dalam Perpres No.112 Tahun 2007 mengacu pada Rencana Tata Ruang Wilayah kabupaten/kota dan Rencana Detail Tata Ruang Wilayah kabupaten/kota, terkait tentang peraturan zonasi. Sementara PerMenDag No.53 tahun 2008 menyatakan bahwa kondisi sosial ekonomi masyarakat merupakan salah satu syarat mutlak dalam pendirian pasar rakyat. Adapun aspek yang dianalisis dalam kondisi sosial ekonomi masyarakat adalah sebagai berikut:

1. Prediksi daya beli masyarakat di suatu daerah yang diperlihatkan melalui struktur penduduk menurut mata pencaharian dan pendidikan, tingkat pendapatan rumah tangga, kepadatan dan pertumbuhan penduduk.

2. Potensi pasar sebagai wahana pemberdayaan ekonomi lokal yang ditunjukkan dengan Kemitraan dengan UMKM lokal, penyerapan tenaga kerja lokal, serta ketahanan dan pertumbuhan pasar rakyat sebagai sarana UMKM lokal.

3. Adanya fasilitas sosial dan fasilitas umum yang menunjang.

4. Jarak antara pasar rakyat dengan pasar modern serta berbagai dampaknya.

5. Aksesibilitas, ketersediaan infrastruktur dan perkembangan pemukiman.

Terkait kondisi sosial ekonomi ini, PerMenDag No.48/M-DAG/PER/8/2013 menjelaskan bahwa pembangunan pasar rakyat harus berada di lokasi yang telah memiliki embrio pasar dan mempertimbangkan luas lahan, daya tampung, bentuk bangunan dan sarana pendukung.

\section{Metode}

Metode penelitian kombinasi (mixed methods) digunakan dalam penelitian tentang pola pertumbuhan pasar rakyat di Kota Pontianak yaitu antara metode kualitatif dan metode kuantitatif dengan metode deskriptif. Ini dimaksudkan untuk mengidentifikasi dan memahami masalah dan menspesifikasikan secara obyektif. Pendekatan kualitatif menjadi pendekatan yang dominan. Sedangkan pendekatan kuantitatif digunakan untuk mendukung dan melengkapi hasil penelitian. Penelitian kuantitatif dilakukan melalui survey dengan mengumpulkan informasi mengenai lokasi, pemilik/pengelola, waktu pelayanan dan bentuk pasar pada seluruh pasar rakyat di Kota Pontianak. Pengumpulan informasi juga dilengkapi dengan sejumlah foto. Teknik pengolahan data kualitatif dilakukan melalui pengumpulan, pengolahan dan persiapan data, men-coding data berdasarkan tema, membuat deskripsi, menghubungkan deskripsi dan menarik kesimpulan.

Penelitian ini dibatasi pada pasar rakyat yang tumbuh dari swadaya masyarakat yang berada di wilayah permukiman yang kemudian secara permanen menjadi tetap dan pedagangnya telah dikenai pembiayaan dalam proses kegiatannya. Selanjutnya pasar yang kemudian dikenai kegiatan penelitian ini adalah pasar rakyat yang berada di permukiman yang cenderung padat namun jauh dari pasar rakyat yang disediakan oleh pemerintah. Kondisi ini dilakukan karena tidak mudahnya pemerintah 
menemukan lokasi atau lahan yang tepat untuk menyediakan pasar rakyat bagi masyarakat di permukiman tersebut.

Penelitian ini didukung oleh data primer dan data sekunder. Data primer diperoleh secara langsung dari lapangan. Data sekunder diperoleh dari hasil dokumentasi dan kompilasi data pihak luar yang terkait. Alat yang digunakan dalam penelitian khususnya dalam pengumpulan data survey adalah kamera, alat tulis dan kuesioner.

Penelitian ini dilakukan dengan menjalankan proses penelitian sesuai tahapan mencapai sasaran penelitian. Identifikasikan proses pertumbuhan pasar rakyat hasil swadaya masyarakat dalam sebuah permukiman dilakukan dengan tahapan sebagai berikut:

1. Identifikasi mengenai lokasi dan pemilik/pengelola seluruh pasar rakyat di Kota Pontianak

2. Identifikasi mengenai waktu pelayanan pada pasar rakyat yang tumbuh dari hasil swadaya masyarakat

3. Identifikasi bentuk pasar yang tumbuh dari hasil swadaya masyarakat pada pasar rakyat dengan waktu pelayanan yang berbeda

Wilayah penelitian ini adalah pada 6 (enam) kecamatan di Kota Pontianak. Adapun kerangka pemikiran dijelaskan pada Gambar berikut.

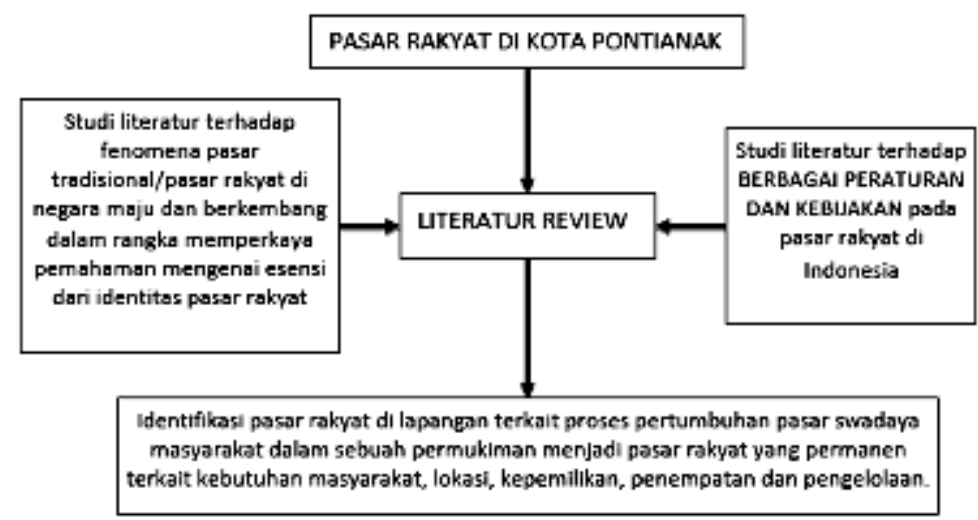

Gambar 1. Kerangka pola pikir penelitian

Sumber: Penulis, 2018

\section{Hasil dan Pembahasan}

\section{Gambaran Umum Kota Pontianak}

Kota Pontianak adalah ibukota Provinsi Kalimantan Barat. Secara geografis, kota ini dilintasi oleh garis Khatulistiwa yaitu pada 0002' 24" LU sampai dengan 0005' 37" LS dan 1090 16' 25" BT sampai dengan 1090 23'01" BT. Kota ini terbelah oleh dua buah sungai utama yaitu Sungai Kapuas dan Sungai Landak dan memiliki sekitar 33 sungai kecil. Kota ini berdekatan dengan daerah lain di Indonesia yang merupakan pusat pertumbuhan regional, seperti Batam, Pekanbaru, Natuna, Balikpapan, Pangkalan Bun dan Jakarta. Kota Pontianak juga tidak jauh dari beberapa kota di negara tetangga seperti Kuching dan Sabah (Malaysia), Bandar Seri Begawan (Brunei Darrusalam) dan Singapura. 


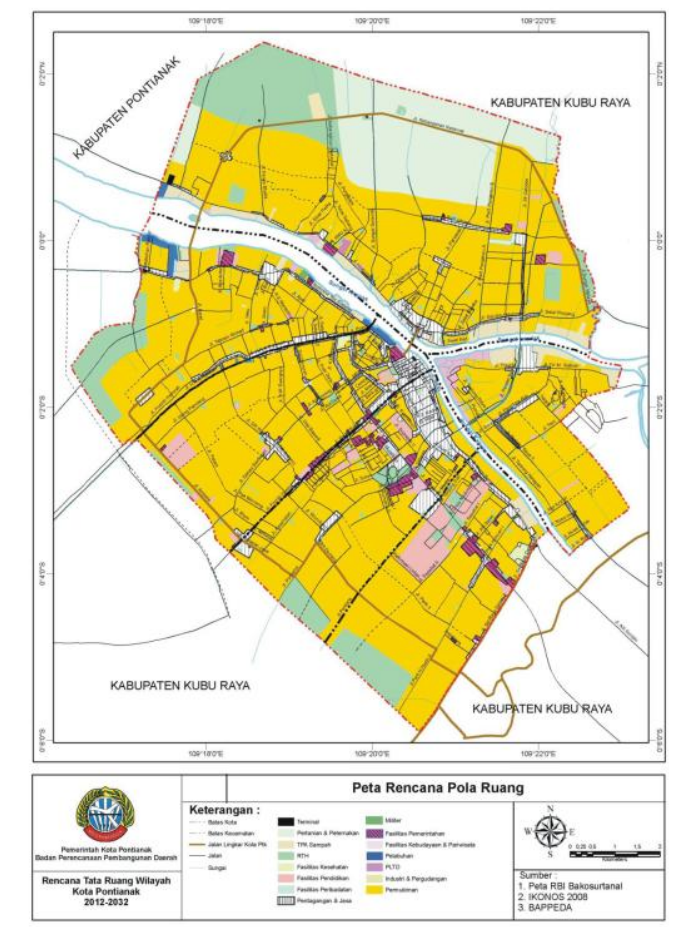

Gambar 2. Peta RTRW Kota Pontianak 2013 - 2033

Sumber: Bappeda Kota Pontianak, 2017

Kota Pontianak yang luas wilayahnya mencapai 107,82 $\mathrm{km}^{2}$, secara administratif memiliki 6 kecamatan yaitu Kecamatan Pontianak Selatan, Pontianak Tenggara, Pontianak Timur, Pontianak Barat, Pontianak Kota dan Pontianak Utara.

Tabel 1. Jumlah Kelurahan, RW dan RT menurut Kecamatan di Kota Pontianak

\begin{tabular}{lrrr}
\hline \multicolumn{1}{c}{ Kecamatan } & Kelurahan & \multicolumn{1}{c}{ RW } & \multicolumn{1}{c}{ RT } \\
\hline Pontianak Tenggara & 4 & 47 & 188 \\
\hline Pontianak Selatan & 5 & 92 & 411 \\
\hline Pontianak Kota & 5 & 120 & 511 \\
\hline Pontianak Barat & 4 & 103 & 548 \\
\hline Pontianak Timur & 7 & 88 & 398 \\
\hline Pontianak Utara & 4 & 132 & 536 \\
\hline \multicolumn{1}{c}{ Jumlah } & 29 & 582 & 2.592 \\
\hline
\end{tabular}

Sumber: Kota Pontianak dalam Angka, BPS, 2017 

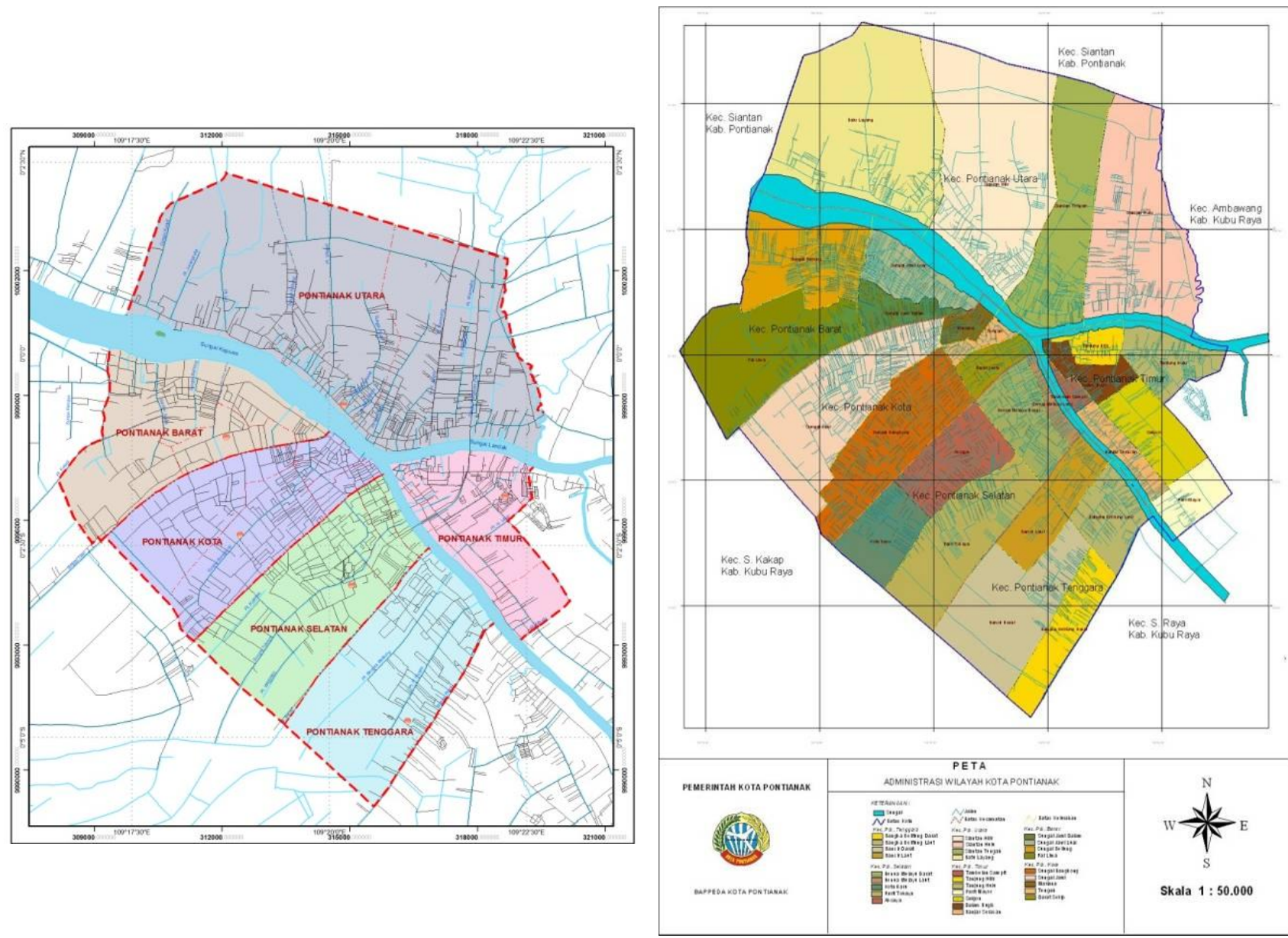

Gambar 3. Peta Administratif (kiri) dan Peta Administratif Kelurahan dan Kecamatan (kanan) Kota Pontianak

Sumber: Bappeda Kota Pontianak, 2017

\section{Pasar Rakyat Kota Pontianak}

Pembahasan lebih lanjut mengenai pasar rakyat di Kota Pontianak, akan dipaparkan berdasarkan masing-masing kecamatan.

\section{A. Kecamatan Pontianak Tenggara}

Pasar rakyat di kecamatan termuda di Kota Pontianak ini berjumlah 4 (empat) buah yang terletak di dua kelurahan yaitu Kelurahan Bangka Belitung Darat dan Kelurahan Bansir Darat. Masing-masing kelurahan memiliki 2 (dua) pasar rakyat yang semuanya merupakan pasar swadaya yang dikelola oleh masyarakat. Meskipun dikelola oleh masyarakat, kecamatan ini memiliki sebuah pasar dengan skala pelayanan kecamatan yaitu Pasar Swadaya di Kelurahan Bangka Belitung Darat. Sementara 3 (tiga) buah pasar lainnya berskala layanan lokal. Meskipun berskala kecamatan, namun warga pada kelurahan tersebut memilih Pasar Flamboyan yang letaknya di di Kecamatan Pontianak Selatan. Pasar Flamboyan juga menjadi pilihan warga di Kelurahan Bangka Belitung Laut yang tidak memiliki pasar. Selain Pasar Flamboyan, warga juga berbelanja di Pasar depan Polda yang merupakan wilayah Kabupaten Kubu Raya. Seluruh pasar beroperasi pagi hari dengan waktu layanan hingga pukul 10.00 dan pukul 13.00 yang masing-masing terdapat di kedua kelurahan. 
Tabel 2. Jumlah Pasar Rakyat di Kecamatan Pontianak Tenggara

\begin{tabular}{lccc}
\hline \multirow{2}{*}{ Kelurahan } & \multicolumn{2}{c}{ Jenis Pasar } & \multirow{2}{*}{ Jumlah } \\
\cline { 2 - 4 } & Pemerintah & Swadaya & \\
\hline Bangka Belitung Laut & 0 & 0 & 0 \\
\hline Bangka Belitung Darat & 0 & 2 & 2 \\
\hline Bansir Laut & 0 & 0 & 0 \\
\hline Bansir Darat & 0 & 2 & 2 \\
\hline & 0 & 4 & 4 \\
\hline
\end{tabular}

Sumber: Survei, 2018

\section{B. Kecamatan Pontianak Selatan}

Jumlah total pasar rakyat di Kecamatan Pontianak Selatan hanya terdapat 4 (empat) buah. Dua buah kelurahan tidak memiliki pasar rakyat yaitu Kelurahan Akcaya dan Kelurahan Benua Melayu Laut. Kelurahan Benua Melayu Darat terdapat sebuah pasar pemerintah yang merupakan pasar utama di Kota Pontianak dengan skala layanan regional dan waktu layanan 24 jam. Warga di Kelurahan Benua Melayu Laut dan Kelurahan Akcaya yang tidak memiliki pasar di sana juga berbelanja di Pasar Flamboyan ini. Selain Pasar Flamboyan, warga di Kelurahan Akcaya juga berbelanja di Pasar Kemuning yang berada di Kelurahan Sungai Bangkong Kecamatan Pontianak Kota. Dua pasar lainnya terdapat di Kelurahan Parit Tokaya yaitu Pasar Purnama Anggrek yang berskala lokal dan dikelola oleh perorangan dan Pasar Dinasti yang berskala kecamatan dan dikelola masyarakat. Kedua pasar beroperasi pagi hari dengan waktu layanan hingga pukul 10.00 untuk Pasar Dinasti dan hingga pukul 13.00 untuk Pasar Purnama Anggrek. Sedangkan 1 (satu) pasar lainnya terdapat di Kelurahan Kota Baru. Pasar ini berskala lokal, dikelola oleh swasta dan beroperasi pagi hari hingga pukul 15.00.

Tabel 3. Jumlah Pasar Rakyat di Kecamatan Pontianak Selatan

\begin{tabular}{lccc}
\hline \multirow{2}{*}{ Kelurahan } & \multicolumn{2}{c}{ Jenis Pasar } & \multirow{2}{*}{ Jumlah } \\
\cline { 2 - 3 } & Pemerintah & Swadaya & \\
\hline Akcaya & 0 & 0 & 0 \\
\hline Parit Tokaya & 0 & 2 & 2 \\
\hline Kota Baru & 0 & 1 & 1 \\
\hline Benua Melayu Laut & 0 & 0 & 0 \\
\hline Benua Melayu Darat & 1 & 0 & 1 \\
\hline \multicolumn{1}{r}{ Jumlah } & 1 & 3 & 4 \\
\hline
\end{tabular}

Sumber: Survei, 2018

\section{Kecamatan Pontianak Kota}

Saat ini Kecamatan Pontianak Barat merupakan kecamatan terpadat ketiga. Jumlah pasar tradisional di wilayah ini adalah sebesar 9 (sembilan) buah. Tiga buah pasar dimiliki oleh pemerintah kota yaitu Pasar Mawar dan Pasar Kapuas di Kelurahan Darat Sekip serta Pasar Kemuning di Kelurahan Sei Bangkong. Ketiga pasar berskala kecamatan dengan waktu pelayanan pagi hingga sore hari. Pada masa lalu, Pasar Mawar dan pasar Kapuas adalah Pasar utama di Kota Pontianak. Sementara itu, 6 (enam) pasar lainnya dikelola oleh masyarakat. Tiga buah pasar berskala kelurahan yaitu 2 (dua) buah pasar di Kelurahan Sungai Bangkong yang beroperasi pagi hari dengan waktu pelayanan hingga pukul 13.00, dan sebuah pasar di Kelurahan Mariana yang juga beroperasi pagi hari hingga pukul 11.00. Sedangkan 3 (tiga) buah pasar lainnya berskala lokal yaitu sebuah pasar di Kelurahan Sungai Bangkong yang beroperasi pagi hari hingga pukul 12.00 dan 2 (dua) buah pasar di Kelurahan Sungai Jawi yang beroperasi pagi hari dengan masing-masing waktu pelayanan hingga pukul 13.00 dan 15.00 . 
Tabel 4. Jumlah Pasar Rakyat di Kecamatan Pontianak Kota

\begin{tabular}{|c|c|c|c|}
\hline \multirow{2}{*}{ Kelurahan } & \multicolumn{2}{|c|}{ Jenis Pasar } & \multirow{2}{*}{ Jumlah } \\
\hline & Pemerintah & Swadaya & \\
\hline Sungai Bangkong & 1 & 3 & 4 \\
\hline Darat Sekip & 2 & 0 & 2 \\
\hline Sungai Jawi & 0 & 2 & 2 \\
\hline Tengah & 0 & 0 & 0 \\
\hline Mariana & 0 & 1 & 1 \\
\hline Jumlah & 3 & 6 & 9 \\
\hline
\end{tabular}

Sumber: Survei, 2018

\section{Kecamatan Pontianak Barat}

Kecamatan Pontianak Barat memiliki pasar rakyat sebanyak 6 (enam) buah. Tiga buah pasar berskala kelurahan dan 3 (tiga) lainnya berskala lokal. Dua buah pasar berskala kelurahan dikelola oleh pemerintah yaitu Pasar Dahlia di Kelurahan Sungai Jawi Dalam dan Pasar Teratai di Kelurahan Sungai Jawi Luar. Kedua pasar beroperasi pagi hari hingga pukul 16.00. Pasar berskala kelurahan lainnya adalah pasar swadaya masyarakat di Kelurahan Sungai Beliung yang beroperasi pagi hari hingga pukul 09.00. Pasar swadaya lainnya terdapat di Kelurahan Sungai Jawi Dalam dan Kelurahan Sungai Jawi Luar masing-masing 1 (satu) buah pasar yang beroperasi pagi hari hingga pukul 09.00 dan pukul 10.00.

Tabel 5. Jumlah Pasar Rakyat di Kecamatan Pontianak Barat

\begin{tabular}{lccc}
\multirow{2}{*}{ Kelurahan } & \multicolumn{2}{c}{ Jenis Pasar } & \multirow{2}{*}{ Jumlah } \\
\cline { 2 - 3 } & Pemerintah & Swadaya & \\
\hline Sungai Jawi Dalam & 1 & 1 & 2 \\
\hline Sungai Jawi Luar & 1 & 1 & 2 \\
\hline Pal Lima & 0 & 0 & 0 \\
\hline Sungai Beliung & 0 & 2 & 2 \\
\hline \multicolumn{1}{r}{ Jumlah } & 2 & 4 & 6 \\
\hline
\end{tabular}

Sumber: Survei, 2018

\section{E. Kecamatan Pontianak Timur}

Kecamatan Pontianak Timur memiliki jumlah kelurahan yang paling banyak di antara kecamatan lainnya di Kota Pontianak. Namun kecamatan ini hanya memiliki 5 (lima) buah pasar rakyat yang berada di 4 (empat) kelurahan yaitu Tambelan Sampit, Dalam Bugis Tanjung Hulu, dan Saigon. Tiga buah pasar merupakan pasar pemerintah. Dua buah pasar berskala kecamatan yaitu Pasar Kenanga dan Pasar Anggrek. Pasar Kenanga berada 2 (dua) kelurahan yaitu Tambelan Sampit dan Dalam Bugis. Pasar ini terletak di lingkungan Keraton dan beroperasi pagi hari hingga pukul 12.00. Pasar Anggrek berada di Kelurahan Tanjung Hulu juga beroperasi pada pagi hari. Sedangkan pasar pemerintah lainnya adalah Pasar Seruni berada di Kelurahan Saigon. Pasar ini berskala kelurahan dan beroperasi pagi hari hingga pukul 11.00. Dua pasar lainnya dikelola oleh masyarakat. Sebuah pasar di Kelurahan Saigon beroperasi pagi hari hingga pukul 11.00. Sebuah cikal bakal pasar berada di Kelurahan Tanjung Hulu dan beroperasi di siang hari. 
Tabel 6. Jumlah Pasar Rakyat di Kecamatan Pontianak Timur

\begin{tabular}{lccc}
\hline \multirow{2}{*}{ Kelurahan } & \multicolumn{2}{c}{ Jenis Pasar } & \multirow{2}{*}{ Jumlah } \\
\cline { 2 - 3 } Tembelan Sampit & Pemerintah & Swadaya & \\
\hline Dalam Bugis & 1 & 0 & \multirow{2}{*}{1} \\
\hline Tanjung Hilir & 0 & 0 & \\
\hline Tanjung Hulu & 1 & 0 & 0 \\
\hline Saigon & 1 & 1 & 2 \\
\hline Banjar Serasan & 0 & 0 & 0 \\
\hline Parit Mayor & 0 & 0 & 0 \\
\hline \multicolumn{1}{r}{ Jumlah } & $\mathbf{4}$ & $\mathbf{2}$ & $\mathbf{5}$ \\
\hline
\end{tabular}

Sumber: Survei, 2018

\section{F. Kecamatan Pontianak Utara}

Kecamatan Pontianak utara memiliki jumlah pasar rakyat yang paling banyak di antara kecamatan lainnya di Kota Pontianak yaitu sebanyak 11 (sebelas) buah pasar. Satu buah pasar berskala kecamatan yang dikelola oleh pemerintah yaitu Pasar puring di Kelurahan Siantan Tengah yang beroperasi selama 24 jam. Lima buah pasar berskala kelurahan yang seluruhnya dikelola oleh masyarakat, terdiri dari 2 (dua) buah pasar di Kelurahan Siantan Tengah yang beroperasi pagi hari hingga pukul 11.00, 2 (dua) buah pasar di Kelurahan Siantan Hilir yang beroperasi dari pagi hingga pukul 17.00 sore serta 1 (satu) buah pasar di Kelurahan Batu Layang yang juga beroperasi pagi hingga pukul 17.00 sore. Sedangkan 5 (lima) buah pasar lainnya merupakan pasar dengan skala layanan lokal yang semuanya berada di Kelurahan Siantan Hulu dan beroperasi pagi hari hingga pukul 10.00.

Tabel 7. Jumlah Pasar Rakyat di Kecamatan Pontianak Utara

\begin{tabular}{lccc}
\hline \multirow{2}{*}{ Kelurahan } & \multicolumn{2}{c}{ Jenis Pasar } & \multirow{2}{*}{ Jumlah } \\
\cline { 2 - 3 } & Pemerintah & Swadaya & \\
\hline Siantan Hulu & 0 & 5 & 5 \\
\hline Siantan Tengah & 1 & 2 & 3 \\
\hline Siantan Hilir & 0 & 2 & 2 \\
\hline Batu Layang & 0 & 1 & 1 \\
\hline \multicolumn{1}{r}{ Jumlah } & 1 & 10 & 11 \\
\hline
\end{tabular}

Sumber: Survei, 2018

Lebih jelas tentang gambaran pasar rakyat di Kota Pontianak terkait jumlah, sebaran lokasi, pengelolaan, skala dan waktu layanan dapat dilihat pada Gambar 4 dan Tabel 8 berikut. 


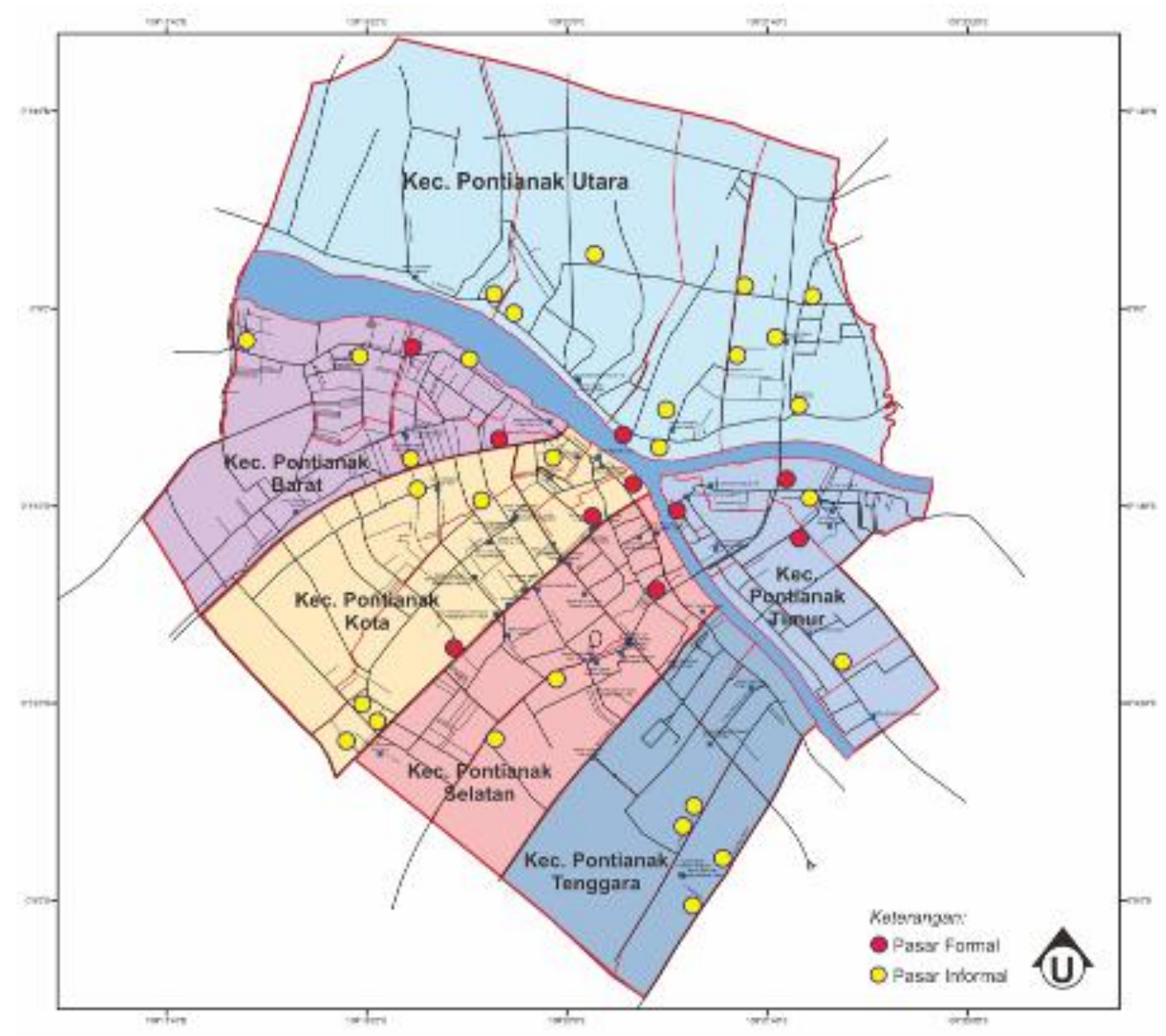

Gambar 4. Sebaran Pasar Rakyat di Kota Pontianak Sumber: Survei, 2018 
Tabel 8. Pasar Rakyat di Kota Pontianak

\begin{tabular}{|c|c|c|c|c|c|c|}
\hline Kecamatan & Kelurahan & Nama Pasar & Alamat & Pengelola & Skala Layanan & Waktu Layanan \\
\hline \multirow{6}{*}{$\begin{array}{l}\text { Pontianak } \\
\text { Tenggara }\end{array}$} & Bangka Belitung Laut & Tidak Ada & \multicolumn{4}{|c|}{$\begin{array}{l}\text { 1. Tidak ada lahan untuk membangun pasar, } 2 \text {. Masyarakat belanja di Pasar Flamboyan dan pasar di Sei. Raya Dalam serta } \\
\text { pasar polda Kubu Raya ataupun warung sembako setempat, } 3 \text {. Merupakan daerah pergudangan }\end{array}$} \\
\hline & \multirow{2}{*}{ Bangka Belitung Darat } & Pasar Swadaya & Gg. Swadaya & Masyarakat & Kecamatan & $05.00-13.00$ \\
\hline & & Pasar M. Saleh & Gg. M. Saleh II & Masyarakat & Lokal & $06.00-10.00$ \\
\hline & Bansir Laut & Tidak Ada Pasar & \multicolumn{4}{|c|}{$\begin{array}{l}\text { 1. Tidak ada lahan untuk di buat pasar, } 2 \text {. Lokasi dekat dengan pasar di kelurahan sekitar, } 3 \text {. Warga belanja di pasar } \\
\text { Flamboyan, 4. Sebagian warga belanja di warung sembako setempat }\end{array}$} \\
\hline & & $\begin{array}{l}\text { Pasar Tumbuh Pemda } \\
\text { Jalur I }\end{array}$ & Jl. Pemda Jalur 1 & Perorangan & lokal & $05.00-13.00$ \\
\hline & Bansir Darat & $\begin{array}{l}\text { Pasar Tumbuh Tegal } \\
\text { Sari }\end{array}$ & Gg. Tegal Sari & Masyarakat & Lokal & $05.00-10.00$ \\
\hline \multirow{6}{*}{$\begin{array}{l}\text { Pontianak } \\
\text { Selatan }\end{array}$} & Akcaya & Tidak Ada Pasar & \multicolumn{4}{|c|}{$\begin{array}{l}\text { 1. Tidak ada lahan untuk di buat pasar, } 2 \text {. Lokasi dekat dengan Pasar Kemuning, } 3 \text {. Tidak ada perencanaan pasar sebelumnya, } \\
\text { 4. Sebagian warga belanja di warung sembako setempat }\end{array}$} \\
\hline & \multirow{2}{*}{ Parit Tokaya } & Pasar Purnama Anggrek & Gg. Purnama Anggrek 1 & Perorangan & lokal & $05.00-13.00$ \\
\hline & & Pasar Gg. Dinasti & Gg. Dinasti & Masyarakat & kecamatan & $06.00-10.00$ \\
\hline & Kota Baru & Pasar Harapan Jaya & Jl. Harapan Jaya & Swasta & lokal & $05.00-15.00$ \\
\hline & Benua Melayu Laut & Tidak Ada Pasar & \multicolumn{4}{|c|}{ 1. Tidak ada lahan, 2. Masyarakat Belanja ke pasar Flamboyan, 3. Sebagian belanja di warung sembako setempat } \\
\hline & Benua Melayu Darat & Pasar Flamboyan & Jl. Pahlawan & Pemerintah & kecamatan & $00.00-24.00$ \\
\hline \multirow{10}{*}{$\begin{array}{l}\text { Pontianak } \\
\text { Kota }\end{array}$} & \multirow{4}{*}{ Sungai Bangkong } & Pasar Kemuning & JI. Sultan Syarir Abdurahman & Pemerintah & Kecamatan & $03.00-15.00$ \\
\hline & & Pasar Ampera & Jl. Ampera & Swadaya/Masyarakat & Kelurahan & $06.00-13.00$ \\
\hline & & Pasar Ikan Ampera & Jl. Ampera & Swadaya/Masyarakat & Kelurahan & $06.00-13.00$ \\
\hline & & Pasar Sentarum & Persimpangan JI. Ampera dan Jl. Danau Sentarum & Swadaya/Masyarakat & Lokal & $06.00-12.00$ \\
\hline & \multirow{2}{*}{ Darat Sekip } & Pasar Mawar & JI. HOS. Cokroaminoto & Pemerintah & Kecamatan & $04.00-17.00$ \\
\hline & & Pasar Kapuas & Jl. Barito & Pemerintah & Kecamatan & $04.00-18.00$ \\
\hline & \multirow{2}{*}{ Sungai Jawi } & Pasar Pancasila V & Gg. Pancasila V & Swadaya & Lokal & $05.00-11.00$ \\
\hline & & Pasar Janur & Gg. Janur & Swadaya & Kelurahan & $05.00-09.00$ \\
\hline & Tengah & Tidak Ada Pasar & 1. Diproyeksikan menjadi kawasan hotel, restoran & syarakat belanja di Pas & wwar \& Pasar di & Mariana \\
\hline & Mariana & Pasar Mariana & Gg. Bangau, Gg. Merak 4 & Swadaya/Masyarakat & Kelurahan & $04.00-11.00$ \\
\hline \multirow{7}{*}{$\begin{array}{l}\text { Pontianak } \\
\text { Barat }\end{array}$} & \multirow{2}{*}{ Sungai Jawi Dalam } & Pasar Era Baru & Gg. Era Baru & Swadaya & Lokal & $07.00-10.00$ \\
\hline & & Pasar Dahlia & JI. Hasanudin & Pemerintah & Kelurahan & $07.00-10.00$ \\
\hline & \multirow{2}{*}{ Sungai Jawi Luar } & Pasar Teratai & Jl. Kom. Yos Sudarso & Pemerintah & Kelurahan & $06.00-16.00$ \\
\hline & & Pasar Belimbing & Gg. Kenari & Swadaya & Lokal & $06.00-09.00$ \\
\hline & Pal Lima & Tidak Ada Pasar & Tidak Ada Keterangan & & & \\
\hline & \multirow{2}{*}{ Sungai Beliung } & Pasar Nipah Kuning & JL. Kom Yos Sudarso & Swadaya/Masyarakat & Lokal & $06.00-13.00$ \\
\hline & & Pasar Landa & Gg. Landak & Swadaya/Masyarakat & Lokal & $06.00-15.00$ \\
\hline
\end{tabular}




\begin{tabular}{|c|c|c|c|c|c|c|}
\hline Kecamatan & Kelurahan & Nama Pasar & Alamat & Pengelola & Skala Layanan & Waktu Layanan \\
\hline \multirow{9}{*}{$\begin{array}{l}\text { Pontianak } \\
\text { Timur }\end{array}$} & Tembelan Sampit & Pasar Kenanga & Komplek Keraton & Keraton/Pemerintah & Kecamatan & $06.00-12.00$ \\
\hline & \multirow{2}{*}{ Saigon } & Pasar Seruni & Jl. Panglima Aim & Pemerintah & Kelurahan & $05.00-11.00$ \\
\hline & & Pasar Tanjung Raya 2 & Jl. Tanjung Raya 2 & Masyarakat & Kelurahan & $03.00-11.00$ \\
\hline & Dalam Bugis & Pasar Kenanga & Komp. Keraton & Pemerintah & Kecamatan & $06.00-12.00$ \\
\hline & Parit Mayor & Tidak Ada Pasar & \multicolumn{4}{|c|}{$\begin{array}{l}\text { Masyarakat berbelanja di warung atau melalui pedagang keliling, } 2 \text {. Sebagian masyarakat berbelanja di pasar rakyat } \\
\text { (Kelurahan Saigon) }\end{array}$} \\
\hline & Tanjung Hilir & Tidak Ada Pasar & \multicolumn{4}{|c|}{ 1. Masyarakat berbelanja di warung atau melalui pedagang keliling, 2. Sebagian masyarakat berbelanja di Pasar Kenanga } \\
\hline & \multirow{2}{*}{ Tanjung Hulu } & Pasar Anggrek & JI. YM. Sabran & Pemerintah & Kecamatan & - \\
\hline & & Dugaan Pasar & Jl. YM. Sabran & Masyarakat & Lokal & Siang Hari \\
\hline & Banjar Serasan & Tidak Ada Pasar & \multicolumn{4}{|c|}{ Masyarakat berbelanja di warung atau melalui pedagang keliling, 2 . Sebagian masyarakat berbelanja di Pasar Kenanga } \\
\hline \multirow{11}{*}{$\begin{array}{l}\text { Pontianak } \\
\text { Utara }\end{array}$} & \multirow{5}{*}{ Siantan Hulu } & Pasar Selat Panjang & Jl. Selat Panjang & Masyarakat & Lokal & $05.00-10.00$ \\
\hline & & Pasar 28 Oktober & Jl. 28 Oktober & Masyarakat & Lokal & $05.00-10.00$ \\
\hline & & Pasar Parit Nanas & Jl. Parit Nanas & Masyarakat & Lokal & $05.00-10.00$ \\
\hline & & Pasar Budi Utomo & Jl. Budi Utomo & Masyarakat & Lokal & $05.00-10.00$ \\
\hline & & Pasar Parit Pangeran & Jl. Parit Pangeran & Masyarakat & Lokal & $05.00-10.00$ \\
\hline & \multirow{3}{*}{ Siantan Tengah } & Pasar Lamtana & Jl. Gusti Situt Mahmud \& Jl. Karimata 3 & Masyarakat/Swadaya & Kelurahan & $03.00-11.00$ \\
\hline & & Pasar Harapan & Gg. Harapan & Masyarakat/Swadaya & Kelurahan & $05.00-11.00$ \\
\hline & & Pasar Puring & Jl. Gusti Situt Mahmud & Pemerintah & Kecamatan & $00.00-24.00$ \\
\hline & \multirow{2}{*}{ Siantan Hilir } & Pasar Budi Utomo & Jl. Budi Utomo & Masyarakat/Swadaya & Kelurahan & $06.00-17.00$ \\
\hline & & Pasar Khatulistiwa & Jl. Khatulistiwa & Masyarakat/Swadaya & Kelurahan & $06.00-17.00$ \\
\hline & Batu Layang & $\begin{array}{l}\text { Pasar Sinar Pelita } \\
\text { Dalam }\end{array}$ & Jl. Sinar Pelita Dalam & Masyarakat/Swadaya & Kelurahan & $06.00-17.00$ \\
\hline
\end{tabular}

Sumber: Survei, 2018 


\section{Pertumbuhan Pasar Rakyat Di Kota Pontianak}

Berdasarkan paparan data sebelumnya, Kota Pontianak memiliki 40 buah pasar rakyat yang tersebar pada hampir seluruh Kelurahan. Dari sekian banyak jumlah pasar rakyat tersebut hanya 11 buah atau $27,5 \%$ yang merupakan pasar rakyat yang disediakan oleh pemerintah, selebihnya yaitu sebesar 29 atau 72,5\% merupakan pasar yang tumbuh dari swadaya masyarakat. Ini menunjukkan bahwa penyediaan fasilitas umum berupa pasar rakyat oleh pemerintah tidak sebanding dengan tingkat kebutuhan masyarakat. Karena itu penting sekali untuk memahami bagaimana proses pertumbuhan pasar rakyat dari swadaya masyarakat ini.

Tabel 9. Penyediaan Pasar Rakyat di Kota Pontianak

\begin{tabular}{ccccc}
\multirow{2}{*}{ No } & \multirow{2}{*}{ Kecamatan } & \multicolumn{2}{c}{ Penyedia Pasar } & \multirow{2}{*}{ Jumlah } \\
\cline { 3 - 4 } & & Pemerintah & Swadaya & \\
\hline 1 & Pontianak Tenggara & 0 & 4 & 4 \\
\hline 2 & Pontianak Selatan & 1 & 3 & 4 \\
\hline 3 & Pontianak Kota & 3 & 6 & 9 \\
\hline 4 & Pontianak Barat & 2 & 4 & 6 \\
\hline 5 & Pontianak Timur & 4 & 2 & 6 \\
\hline 6 & Pontianak Utara & 1 & 10 & 11 \\
\hline & TOTAL & $\mathbf{1 1}$ & $\mathbf{2 9}$ & $\mathbf{4 0}$
\end{tabular}

Sumber: Survei, 2018

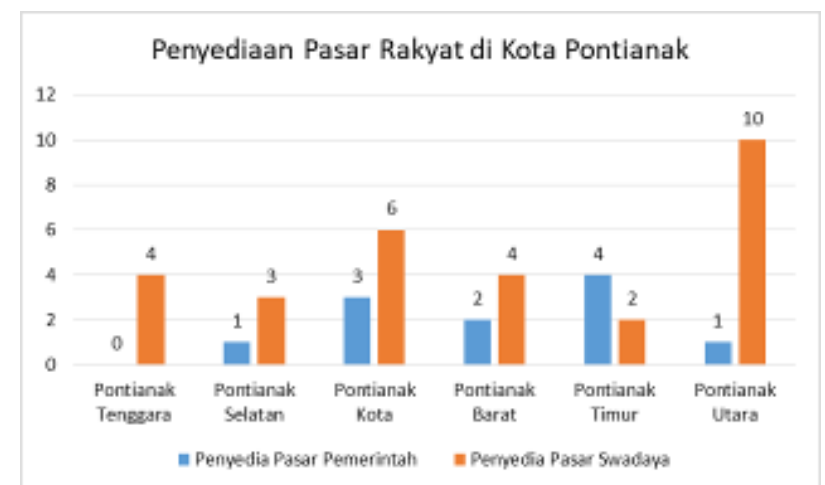

Gambar 5. Penyediaan pasar rakyat di Kota Pontianak Sumber: Survei, 2018

Pasar rakyat hasil swadaya ini berkembang dari adanya sebuah warung atau beberapa warung yang menjual sembako di area permukiman yang banyak dikunjungi oleh penduduk di sekitarnya. Ramainya kunjungan pembeli ini kemudian diikuti dengan kehadiran pedagang-pedagang kecil yang menggelar dagangannya di sekitar warung tersebut. Lambat laun, pedagang yang berada di wilayah tersebut semakin bertambah seiring dengan bertambahnya pembeli dan kebutuhan barang dagangan yang diinginkan masyarakat sekitar. Pedagang-pedagang kecil yang hadir di sekitar warung di area permukiman ini, merupakan wujud nyata dari eksistensi perekonomian di Kota Pontianak.

Tabel 10. Jumlah Pedagang di Pasar Rakyat Swadaya di Kota Pontianak

\begin{tabular}{|c|c|c|c|c|}
\hline \multirow{2}{*}{ No } & \multirow{2}{*}{ Kecamatan } & \multicolumn{2}{|c|}{ Jumlah Pedagang } & \multirow{2}{*}{ Jumlah } \\
\hline & & $<30$ & $>=\mathbf{3 0}$ & \\
\hline 1 & Pontianak Tenggara & 3 & 1 & 4 \\
\hline 2 & Pontianak Selatan & 3 & 0 & 3 \\
\hline 3 & Pontianak Kota & 3 & 3 & 6 \\
\hline 4 & Pontianak Barat & 3 & 1 & 4 \\
\hline 5 & Pontianak Timur & 2 & 0 & 2 \\
\hline 6 & Pontianak Utara & 10 & 0 & 10 \\
\hline & TOTAL & 24 & 5 & 29 \\
\hline
\end{tabular}

Sumber: Survei, 2018 


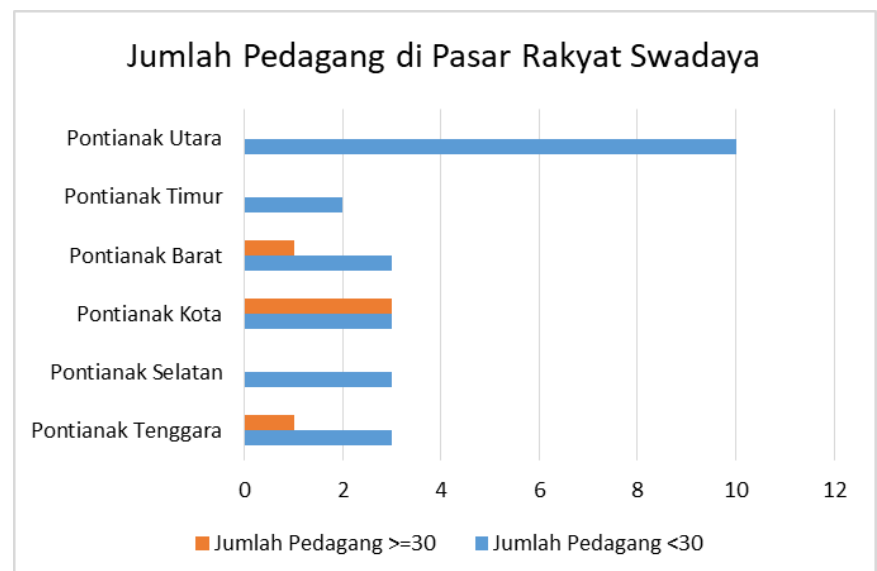

Gambar 6. Jumlah pedagang di pasar rakyat swadaya di Kota Pontianak Sumber: Survei, 2018

Berbeda dari hasil revitalisasi pasar rakyat milik pemerintah yang tak jarang ditinggalkan oleh pedagangnya, keberadaan pasar rakyat hasil swadaya masyarakat di Kota Pontianak ini cukup signifikan baik dalam jumlah, bentuk pasar hingga keberlanjutannya. Ini terlihat dari terus berkembangnya jumlah pedagang hingga bentuk pasar sejak mulai embrio pasar terbentuk, hingga berlangsungnya kegiatan pasar ini setiap hari baik pagi, siang maupun sore hari. Saat ini, pasar rakyat yang beroperasi sejak pagi hari hingga siang hari adalah sebanyak 23 pasar rakyat atau 79,3\%. Sedangkan pasar rakyat yang beroperasi sejak pagi hari hingga sore hari sebanyak 6 pasar rakyat atau $20,7 \%$.

Tabel 11. Waktu Pelayanan Pasar Rakyat Swadaya di Kota Pontianak

\begin{tabular}{ccccc}
\multirow{2}{*}{ No } & \multirow{2}{*}{ Kecamatan } & \multicolumn{2}{c}{ Waktu Pelayanan } & \multirow{2}{*}{ Jumlah } \\
\cline { 3 - 4 } & & Pagi - Siang & Pagi - Sore & \\
\hline 1 & Pontianak Tenggara & 4 & 0 & 4 \\
\hline 2 & Pontianak Selatan & 2 & 1 & 3 \\
\hline 3 & Pontianak Kota & 6 & 0 & 6 \\
\hline 4 & Pontianak Barat & 3 & 1 & 4 \\
\hline 5 & Pontianak Timur & 2 & 0 & 2 \\
\hline 6 & Pontianak Utara & 7 & 3 & 10 \\
\hline & TOTAL & $\mathbf{2 4}$ & $\mathbf{5}$ & $\mathbf{2 9}$
\end{tabular}

Sumber: Survei, 2018

Waktu pelayanan pasar rakyat ini umumnya disesuaikan dengan kegiatan berbelanja penduduk. Waktu pelayanan di pagi hari hingga siang hari diperuntukkan bagi pelaku pasar rakyat secara umum. Sedangkan waktu pelayanan hingga sore hari umumnya diperuntukkan bagi pengunjung yang berbelanja setelah pulang kerja. Berdasarkan jumlah dan kelas pedagang, waktu operasional serta berkembang dan bertahannya keberadaan pasar rakyat ini, sangat signifikan menunjukkan adanya minat dan daya beli masyarakat yang memadai.

Sementara itu, potensi lain yang dapat dijadikan elemen penentu dari penyediaan fasilitas pasar rakyat ini adalah lokasi. Hampir seluruh pasar rakyat yang tumbuh dan berkembang dari swadaya masyarakat berada di kawasan permukiman yaitu sebanyak 22 pasar rakyat atau $76 \%$. Sedangkan pasar rakyat yang berada di kawasan perdagangan hanya sebanyak 7 pasar rakyat atau 24\%. Ini menunjukkan bahwa keberadaan pasar rakyat di Kota Pontianak hakikatnya dibutuhkan oleh penduduk di kawasan permukiman. Semakin padat penduduk sebuah kawasan permukiman, semakin banyak pula pasar rakyat hasil swadaya masyarakat ini tumbuh dan berkembang.

Pengunjung pasar rakyat pada sebuah wilayah permukiman belum tentu hanya berasal dari permukiman tempat pasar rakyat itu berada. Tapi juga berasal dari permukiman-permukiman sekitar. 
Ini menunjukkan bahwa kondisi sosial ekonomi, atau daya beli masyarakat tidak hanya dapat diprediksi dari permukiman tempat pasar rakyat itu berada, tapi juga dari permukiman sekitarnya. Prediksi ini sudah sangat diperhitungkan oleh para pedagang dalam memilih lokasi untuk berdagang mereka. Itu sebabnya hampir seluruh pasar rakyat hasil swadaya masyarakat ini berada di jalan yang merupakan jalur lintas antar 2 (dua) buah jalan atau kawasan. Semakin panjang jalur lintasan ini, semakin besar pula berkembangnya pasar rakyat yang terbangun.

Hal lain yang cukup mempengaruhi berkembangnya pasar rakyat hasil swadaya masyarakat pada jalur lintasan ini adalah, kemudahan pencapaian jalur lintasan tersebut. Semakin mudah diakses semakin mudah berkembang pasar rakyat. Kemudahan akses ini hanya terkait pencapaian semata. Artinya jika jalan tersebut dapat dicapai dan dekat dari berbagai jalur di sekitarnya maka jalan ini dikatakan mudah untuk diakses. Kemudahan pencapaian tidak terkait dengan keberadaan transportasi umum di jalan tersebut. Kedekatan pencapaian ini merupakan indikasi utama dalam tumbuhnya embrio pasar rakyat hasil swadaya pada sebuah kawasan. Sebagai contoh, wilayah Kecamatan Pontianak Kota yang merupakan pemekaran dari Kecamatan Pontianak Barat, tadinya memiliki Pasar Dahlia sebagai pasar rakyat yang cukup lengkap yang disediakan oleh pemerintah. Namun karena jarak yang cukup jauh bagi kelurahan yang berada di bagian timur Kecamatan Sei Jawi, maka pada Kelurahan Sei Jawi dan Mariana di Kecamatan Pontianak Kota ini muncul pasar rakyat swadaya yang cukup kuat keberadaannya hingga saat ini.

Selain adanya warung yang ramai, jalur lintasan, kehadiran para pedagang ini juga didukung oleh adanya area untuk menggelar dagangan baik berupa bahu jalan maupun berupa lahan kosong. Lebar jalan maupun lebar bahu jalan juga cukup berpengaruh terhadap kemunculan pedagangpedagang kecil di sekitar warung sembako pada jalan tersebut. Semakin lebar jalan atau bahu jalan semakin besar pula perkembangan yang bisa terjadi pada sebuah pasar rakyat hasil swadaya masyarakat di jalan tersebut.

Tabel 12. Zona Peruntukan Lokasi Pasar Rakyat Swadaya di Kota Pontianak

\begin{tabular}{|c|c|c|c|c|}
\hline \multirow{2}{*}{ No } & \multirow{2}{*}{ Kecamatan } & \multicolumn{2}{|c|}{ Zona Peruntukan } & \multirow{2}{*}{ Jumlah } \\
\hline & & Permukiman & Perdagangan & \\
\hline 1 & Pontianak Tenggara & 4 & 0 & 4 \\
\hline 2 & Pontianak Selatan & 2 & 1 & 3 \\
\hline 3 & Pontianak Kota & 5 & 1 & 6 \\
\hline 4 & Pontianak Barat & 3 & 1 & 4 \\
\hline 5 & Pontianak Timur & 1 & 1 & 2 \\
\hline 6 & Pontianak Utara & 7 & 3 & 10 \\
\hline & TOTAL & 22 & 7 & 29 \\
\hline
\end{tabular}

Sumber: Survei, 2018

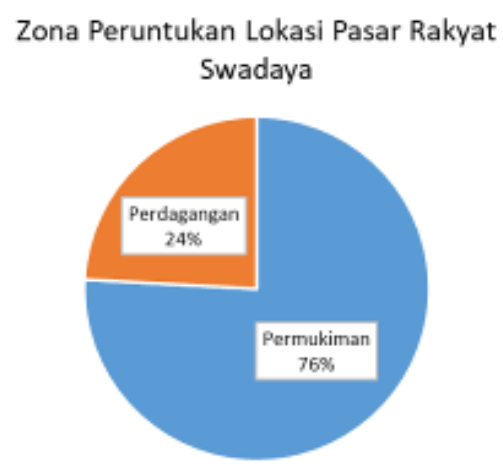

Gambar 7. Diagram perbandingan lokasi pasar rakyat swadaya di Kota Pontianak Sumber: Survei, 2018 


\section{Kesimpulan}

Perkembangan pasar rakyat yang terbentuk dari swadaya masyarakat di Kota Pontianak menunjukkan jumlah yang signifikan yaitu sebesar $72,5 \%$ dari jumlah total pasar yang ada. Ini menunjukkan pasar rakyat yang disediakan oleh pemerintah tidak sebanding dengan tingkat kebutuhan masyarakat. Pasar rakyat swadaya ini tumbuh dan berkembang seiring tingkat kebutuhan masyarakat. Semakin bertambah jumlah penduduk di suatu wilayah, semakin bertambah pula jumlah pasar rakyat di wilayah tersebut. Pasar-pasar rakyat ini bahkan berkembang semakin besar dengan waktu pelayanan yang cukup panjang dan menggunakan area yang cukup luas pula.

Jumlah yang cukup signifikan, waktu operasional yang setiap hari hingga pengelolaan yang semakin terorganisir menunjukkan bahwa, lokasi keberadaan pasar rakyat yang berkembang di Kota Pontianak ini sangat signifikan menunjukkan adanya minat dan daya beli masyarakat yang memadai baik dari pemukim di permukiman tempat pasar rakyat itu berada, maupun juga dari pemukim di permukiman sekitarnya.

Selain banyak di area permukiman, lokasi pasar rakyat swadaya ini tumbuh pada jalur lintas antar 2 (dua) buah jalan atau kawasan. Semakin mudah akses dan semakin panjang jalur lintasan ini, semakin besar pula berkembangnya pasar rakyat yang terbangun. Perkembangan akan semakin signifikan jika pada jalur lintas tersebut terdapat area yang cukup untuk menggelar dagangan.

Pola pertumbuhan pasar rakyat di Kota Pontianak yang terbentuk dari swadaya masyarakat Kota Pontianak dalam penelitian ini sangat relevan untuk menjadi pertimbangan dalam penataan pasar rakyat di Kota Pontianak di masa yang akan datang. Ini terkait pada kebutuhan masyarakat, lokasi, kepemilikan, penempatan dan pengelolaan.

\section{Daftar Pustaka}

Appel, D., (1972). The supermarket: early development of an institutional innovation. Journal of Retailing 48 (Spring), 39-52.

Cook, I. (2008). Geographies of food: mixing, Progress in Human Geography 32(6): 821833.

Findlay, A., Paddison, R., Dawson, J. (Eds.), (1990), Retailing Environments in Developing Countries. Routledge, London.

Goldman, A., (1981). Transfer of a retailing technology into less developed countries: the supermarket case. Journal of Retailing 57 (2), 5-29.

Goldman, A., and Hayiel Hino, (2005). Supermarkets vs. traditional retail stores: diagnosing the barriers to supermarkets' market share growth in an ethnic minority community. Journal of Retailing and Consumer Services. pp. 273-284.

Gonzalez, S and Waley, P. (2013). Traditional Retail Markets: The New Gentrification Frontier? Antipode: a radical journal of geography, 45 (4). 965 - 983. ISSN 0066-4812.

Heldke, L. (2003). Exotic Appetites: Ruminations of a Food Adventurer. London: Routledge.

Hendrakusumah, E. (2014). Penanganan Permukiman Kumuh Berbasis Kawasan Bernilai Tambah dan Berkelanjutan. Seminar Nasional. UNISBA.

Kaynak, E., Cavusgil, T., (1982). The evolution of food retailing systems: contrasting the experience of developed and developing Countries. Journal of the Academy of Marketing 10 (3), 249-269.
Kementerian Perdagangan, BPPKP, Pusat Kebijakan Perdagangan Dalam Negeri. (2012). Peran Revitalisasi Terhadap Kinerja Pasar Tradisional.

Kumcu, E., Kumcu, M., (1987). Determinants of food retailing in developing countries: the case of Turkey. Journal of Macromarketing 7 (fall), 26-40.

Lagerkvist, et al. (2015). Consumers' evaluation of volition, control, anticipated regret, and perceived food health risk. Evidence from a field experiment in a traditional vegetable market in Kenya. Food Control 47, pp. 359-368.

Lupitosari, D. (2011). Dampak Jumlah Pasar dan Jumlah Pedagang Terhadap Pertumbuhan Ekonomi Kota Surakarta Sebelum Dan Sesudah Kebijakan Revitalisasi Pasar Tradisional. Skripsi. Surakarta - F. Ekonomi.

Peraturan Menteri Perdagangan Republik Indonesia No. 48 Tahun 2013 tentang Pedoman Pembangunan dan Pengelolaan Sarana Distribusi Perdagangan

Peraturan Menteri Perdagangan Republik Indonesia No. 70 Tahun 2013 tentang Pedoman Penataan dan Pembinaan Pasar Tradisional, Pusat Perbelanjaan dan Toko Modern

Peraturan Menteri Perdagangan Republik Indonesia No. 53 Tahun 2008 tentang Pedoman Penataan dan Pembinaan Pasar Rakyat, Pusat Perbelanjaan dan Toko Modern

Peraturan Presiden Republik Indonesia No. 112 Tahun 2007 tentang Penataan dan Pembinaan Pasar 
Tradisional, Pusat Perbelanjaan dan Toko Modern

Schipmann, C., \& Matin Qaim. (2011). Supply Chain Differentiation, Contract Agriculture, and Farmers' Marketing Preference: The Case of Sweet Pepper in Thailand. Globalfood Discussion Papers.
Slater, C. and Henley, D. (1969). Market processes in La Paz, Bolivia, Latin American Studies Center. Michigan State University, East Lansing.

Suryadarma, et al. (2009). Dampak Supermarket terhadap Pasar dan Pedagang Ritel Tradisional di Daerah Perkotaan di Indonesia. SMERU. 